\title{
LEGAL AND REGULATORY FRAMEWORK OF BLOOD ESTABLISHMENTS OF UKRAINE
}

\author{
Zhytomyr Regional Blood Center, Ukraine
}

\begin{abstract}
Purpose: to determine the status of legal and regulatory that regulates activities of blood service establishments of Ukraine as of 01.01.2013.

Materials and methods. Operating documents that regulated activity of blood service in Ukraine were studied.

Results. It is established that the activities of blood service establishments in Ukraine regulating 107 legal acts, including 15 Laws of Ukraine, 2 Decrees of the President of Ukraine, 16 Resolutions of the Cabinet of Ministers of Ukraine, 37 Orders of Ministry of Health of Ukraine, 14 intergovernmental orders, 9 Orders of Ministry of Health of USSR and Ukrainian SSR, 1 Resolution of the USSR State Committee on standards and 10 guidelines of Ministry of Health and National Academy of Medical Sciences of Ukraine. Have limitation period up to 5 years 19 acts, from 5-10 years - 25 documents, from 10 to 15 years - 35 certificates, from 15 to 20 years - 13 acts, from 20 to 25 years - 8 acts and $25-$ 40 years have 7 legal and regulatory acts.

Conclusions. The standard base of blood service of Ukraine demands harmonisation with recommendations and resolutions WHO and the Council of Europe, Guidelines on production, use and quality assurance of blood components.

KEY WORDS: legal and regulatory framework, blood service, statistical reporting forms, haemovigilance system, legislation of the European Union.
\end{abstract}

Realization of the right of each individual for health, availability and quality of medical care requires improvement of the models of health care systems of any country regardless of political structure and economic status. As a rule every 10 years countries make changes in their own models. However, there was not any significant progress in health care system of Ukraine during 50-year period, except some changes in the amount of funding and the remuneration level of medical workers labour [1].

When introducing changes in health care models primary role should be assigned to the creation of appropriate legal and regulatory framework, adequate resource support, including financial, human and logistical support and implementation of modern effective management. In documents of WHO and European Union the main strategic goals of modern principles of blood service model functioning, development and improvement to justify the evolutionary or reformatory changes in national blood service system are outlined. Law of Ukraine "On the State Programme of Adaptation of Ukrainian legislation to the legislation of European Union" determined that the state policy of Ukraine concerning legislation approximation is formed as part of legal reform in Ukraine and is aimed at ensuring common approaches to designing standards and obligatory consideration of legislation requirements of European Union [2]. Research of

(C) A.M. Chuhriiev, 2014 the current legal framework of blood service activities will allow to design an action plan to adjust national legislation in accordance with international documents that will be a determinant prerequisite for the efficient functioning of blood services in future.

The aim of the study is to determine the status of legal and regulatory framework that regulates activities of blood service establishments of Ukraine as of 01.01.2013.

Object and methods. Laws of Ukraine, Decree of the President of Ukraine, Resolutions of Verkhovna Rada of Ukraine, Decisions and Orders of the Cabinet of Ministers of Ukraine, Orders USSR Ministry of Health, Ministry of Health of Ukraine and other ministries, departments and agencies. As the regulatory framework for the production of blood products as medicinal products is regulated by Ukrainian Pharmacopoeia and other international acts and pharmacopoeia, analysis of its condition in this article was not carried out.

Results and Discussion. Legal and regulatory framework of blood service establishments consists of 107 legal and regulatory acts adopted in different years. During the period of existence of the state of Ukraine there were adopted 96 legislative and legal acts, that is $89.7 \%$ of legal and regulatory framework of blood service (Table).

Among the legislative acts there are 15 Laws of Ukraine, 2 Decrees of the President of Ukraine, 16 Resolutions of the Cabinet of Ministers of Ukraine, 37 Orders of Ministry of Health of Ukraine, 14 
Table. Structure of legal and regulatory framework

\begin{tabular}{|c|c|c|c|c|c|c|c|c|c|}
\hline Document & $\begin{array}{l}\text { Up to } \\
5 \text { years }\end{array}$ & $\begin{array}{l}\text { From } \\
5 \text { to } 10 \\
\text { years }\end{array}$ & $\begin{array}{c}\text { From } \\
10 \text { to } 15 \\
\text { years }\end{array}$ & $\begin{array}{c}\text { From } \\
15 \text { to } 20 \\
\text { years }\end{array}$ & $\begin{array}{c}\text { From } \\
20 \text { to } 25 \\
\text { years }\end{array}$ & $\begin{array}{c}\text { From } \\
25 \text { to } 30 \\
\text { years }\end{array}$ & $\begin{array}{c}\text { From } \\
30 \text { to } 35 \\
\text { years }\end{array}$ & $\begin{array}{c}\text { From } \\
35 \text { to } \\
40 \text { years }\end{array}$ & Total \\
\hline Law of Ukraine & 4 & 1 & 6 & 1 & 3 & & & & 15 \\
\hline $\begin{array}{l}\text { Decree of the President of } \\
\text { Ukraine }\end{array}$ & 1 & 1 & & & & & & & 2 \\
\hline $\begin{array}{l}\text { Resolution of the Cabinet of } \\
\text { Ministers of Ukraine }\end{array}$ & 1 & 2 & 8 & 5 & & & & & 16 \\
\hline $\begin{array}{l}\text { Order of Ministry of Health of } \\
\text { Ukraine }\end{array}$ & 8 & 12 & 11 & 5 & 1 & & & & 37 \\
\hline Guidelines, instructions & 3 & 5 & 2 & & & & & & 10 \\
\hline $\begin{array}{l}\text { Orders of other ministries, } \\
\text { departments and services }\end{array}$ & 2 & 4 & 6 & 2 & & & & & 14 \\
\hline $\begin{array}{l}\text { Resolution of Head Health Officer } \\
\text { of Ukraine }\end{array}$ & & & 2 & & & & & & 2 \\
\hline $\begin{array}{l}\text { Order of Head Health Officer of } \\
\text { USSR }\end{array}$ & & & & & 1 & & & & 1 \\
\hline $\begin{array}{l}\text { Order of Ministry of Health of } \\
\text { USSR and Ukrainian SSR }\end{array}$ & & & & & 3 & 6 & & 1 & 10 \\
\hline $\begin{array}{l}\text { Resolution of USSR State } \\
\text { Committee on Standards }\end{array}$ & & & & & & & 1 & & 1 \\
\hline Total & 19 & 25 & 35 & 13 & 8 & 6 & 1 & 1 & 108 \\
\hline
\end{tabular}

interdepartmental orders, 9 Orders of Ministry of Health of USSR and Ukrainian SSR, 1 Resolution of USSR State Committee on standards and 10 guidelines of Ministry of Health and National Academy of Medical Sciences of Ukraine.

By term of adopting the documents were distributed as follows: up to 5 years (2008-2012) 19 documents (4 Laws of Ukraine, 1 Decree of the President of Ukraine, 1 Resolution of the Cabinet of Ministers, 8 Orders of Ministry of Health of Ukraine, 2 interdepartmental orders, 3 guidelines of Ministry of Health and NAMS of Ukraine). During 2003-2007 (5-10 years) 25 documents were adopted: 1 Law of Ukraine, 1 Decree of the President of Ukraine, 2 Resolutions of the Cabinet of Ministers, 12 Orders of Ministry of Health of Ukraine, 4 interdepartmental orders, 5 Guidelines of Ministry of Health and NAMS of Ukraine. The largest part of documents are legal acts adopted during 1998-2002, 35 documents ranging from 10 to 15 years, including 6 Laws of Ukraine, 8 Resolutions of the Cabinet of Ministers, 11 Orders of Ministry of Health of Ukraine, 8 interdepartmental orders, 2 guidelines of Ministry of Health and NAMS of Ukraine. During 1993-1997 there were adopted 13 documents including 1 Law of Ukraine, 5 Resolutions of the Cabinet of Ministers of Ukraine, 5 Orders of Ministry of Health of Ukraine and 2 Orders of State Standard of Ukraine. From 1988 to
1992 eight documents were adopted - 3 Laws of Ukraine, 1 Order of Ministry of Health of Ukraine, 1 interdepartmental order, 3 Orders of Ministry of Health of USSR and Ukrainian SSR.

Composition of current work with donors and potential donors is determined by 25 legislative and legal acts; blood procurement, blood components manufacturing, storage and transportation are regulated by 23 documents; laboratory support (clinical, biochemical, immunological and bacteriological tests) is determined by 10 documents; composition of quality system in blood service establishments is governed by 12 documents; procedure of donor blood screening for transfusion-transmissible infections is determined by 22 acts; activities on transfusion assistance and information analysis are regulated by 13 regulatory acts; metrological support, facilities criteria and requirements for compliance with sanitary and epidemiological welfare are regulated by 32 legal and regulatory documents.

The work of a unitary donor center is governed by 25 acts, including 2 documents - up to 5 years, 9 acts - from 5 to 10 years, 4 documents - from 10 to 15 years, 4 documents $-15-20$ years and 3 documents more than 20 years (Order of USSR Ministry of Health from 12.07.1989 No. 408 "On Measures on Reduction of Incidence Level of Hepatitis in the Country", Order of Ministry of Health 
from 09.11.1988 No. 06-14 / 39, which approved the "Instruction for Platelets Procurement from Single Donor by Intermittent Thrombocytapheresis Using Polymerous Containers", Order of Ministry of Health from 10.02.1988 No. 91 "On Obligatory Testing of Donors for HIV"). The adoption of Law of Ukraine "On Personal Data Protection" requires amendments to the registration forms for donors. Obtaining of specific plasma as raw materials for plasma products stipulates the reviewing of methods (order) of donor immunization or introduction of other technologies of diagnostics of specific antibodies due to natural or artificial immunity.

Blood and blood components procurement, storage conditions and transportation are regulated by 23 documents adopted at different periods. Among them 3 regulatory acts are under 5 years, 7 documents - from 5 to 10 years, 6 acts - from 10 to 15 years, 3 acts $-15-20$ years and 4 acts 20-30 years: Order of USSR Ministry of Health from 09.11.1988 No. 06-14 / 39 Instruction "Platelets Procurement from a Single Donor by Intermittent Thrombocytapheresis"; Order of USSR Ministry of Health from 12.07.1989 No. 408 "On Measures on Reduction of Incidence Level of Hepatitis in the Country"; Order of USSR Ministry of Health from 10.06.1985 No. 770 «On Consummation of Trade Standard OST 42-21-85 "Sterilization and Disinfection of Goods for Medical Purposes. Methods, means and conditions"; Order of USSR Ministry of Health from 30.08.1984 No. 06-14/10 "Instruction on Procurement of Preserved Donor Blood". During last 20 years new technologies using appropriate equipment were implemented in blood service establishments: hardware apheresis of plasma and blood cells including stem cells from the peripheral circulatory system, formation of pools of platelets from whole blood units, virus inactivation in blood components for transfusion, formation of cold chain during storage and transportation of blood and blood components etc. New technologies with introduction of new technological equipment require a certain mechanism of legalization and procedure of their usage in blood service establishments, that is why it is necessary to develop regulatory documentation. There is no regulatory documentation concerning plasma for fractionation, blood components for perinatal use and use in children, cold chain conditions for blood product transportation and usage of autologous blood according to the requirements and recommendations of WHO and Council of Europe.

Laboratory support (clinical, biochemical, immunological bacteriological tests) is regulated by 10 legal and regulatory documents: 1 Law of Ukraine, 4 Orders of Ministry of Health of Ukraine, 1 Order of State Committee on Issues of Technical Regulation and Consumer Policy, 3 Orders of USSR Ministry of
Health and 3 Guidelines of Ministry of Health of Ukraine and NAMS of Ukraine. They are aged: 1 document up to 5 years; 4 - from 5 to 10 years; 1 - from 10 to 15 years; 1 - from 15 to 20 years and 1 - from 20 to 25 years and 2 - over 25 years: Order of USSR Ministry of Health from 07.09.1990 No. 05-14/28 "Instruction on Preparation of Standard Sera and Antirhesus Reagent"; Order of USSR Ministry of Health from 23.04.1985 No. 545 "On Further Improvement of Quality Control of Clinical Laboratory Trials"; Order of USSR Ministry of Health from 30.08.1984 No. 06-14/10 which approved the "Instruction on Procurement of Preserved Donor Blood."

Laboratory trials in developed countries are run using hardware approach, especially where the error is worth a human life. Technologies of immune hematological trials and organization of internal quality control system remain obsolete. It is necessary to develop documentation for creation of external quality assessment system with the determination of appropriate reference laboratories by Ministry of Health of Ukraine in order to investigate transfusion complications and reactions. Regulatory framework of sterility control taking into account new technologies of blood procurement, blood components manufacturing and new methods for sterility research needs changes.

Regulations of donor blood testing for transfusion-transmissible infections are determined by 22 legal and regulatory documents: 3 Laws of Ukraine, 1 Decree of the President of Ukraine; 4 Resolutions of the Cabinet of Ministers of Ukraine; 9 Orders of Ministry of Health of Ukraine; 2 Resolutions of Head Health Officer of Ukraine; 2 Orders of USSR Ministry of Health and 1 Order of Ministry of Health of Ukrainian SSR. By term of adoption documents were distributed as follows: up to 5 years -3 acts; from 5 to 10 years -4 acts; from 10 to 15 years - 8 acts; from 15 to 20 years 3 acts; from 20 to 25 or more -4 documents including 1 Law of Ukraine 1992, Order of USSR Ministry of Health from 12.07.1989 No. 408 "On Measures on Reduction of Incidence Level of Hepatitis in the Country"; Order of USSR Ministry of Health from 10.02.1988 No. 91 "On Obligatory Donor Blood Testing for HIV"; Order of USSR Ministry of Health from 15.06.1987 No. 426-DSP "On Task Performance in Fight against AIDS in Ukrainian SSR." In 2013 there was adopted a new Procedure of donor blood screening which needs the next step - creating the regulatory framework concerning organization of intra-laboratory quality control and continuous involvement of laboratories in external quality assessment system.

Organization of transfusion assistance and information analysis of blood service establishments are regulated by 14 legal documents: 1 Law of Ukraine and 1 Decree of the President, 
2 Resolutions of the Cabinet of Ministers of Ukraine and 10 Orders of Ministry of Health of Ukraine. Distribution by term of adoption looks as follows: up to 5 years - 2 documents; $5-10$ years -5 documents; 10-15 years - 5 documents; 15-25 years - 1 Resolution of the Cabinet of Ministers of Ukraine and 1 Law of Ukraine "On State Statistics"; more than 25 years - Order of USSR Ministry of Health from 23.05.1985 No. 700. Basic statistical reporting forms were approved in 2003. In 2010 Order of Ministry of Health approved a new nomenclature of blood components, which require introduction of new technologies (hardware plasmapheresis, leuko filtration of blood and its components, virus inactivation of blood components, pooled platelets from preserved blood, etc.) requiring appropriate amendments to the accounting and reporting forms. Future changes in the model of national healthcare system will set conditions for a formation of blood service status at legislative and state level that will stimulate systemic changes in blood service structure and financial and legal relations in national health care system, especially when administering health insurance system. According to Order of Ministry of Health from 28.10.2002 No. 385 blood transfusion establishments have three names, their functions are not defined by the Regulations and the structure and staff need changes. Nowadays blood service management at the state level according to Decree of the President from 08.04.2011 No. 4441/2011 has decentralized structure with different levels of subordination without a defined development strategy.

Organization of quality control of preserved blood and blood components is regulated by 12 legal documents: 3 Laws of Ukraine, 4 Orders of Ministry of Health of Ukraine, 1 interdepartmental order and 4 Guidelines of Ministry of Health and NAMS of Ukraine. Among them 4 documents are under 5 years; 5 documents - from 5 to 10 years; 1 - from 10 to 15 years; 2 - from 15 to 20 years. Quality control of blood components is virtually a control of stability and standards of manufacturing process of blood components production, including all stages of blood service activities starting from medical examination of a donor to clinical use of blood components. As of today the main stages of procurement technologies do not exclude subjective approaches that affect the quality of the final product. Implementation of a quality system will guarantee the safety and clinical efficacy of transfusion environments. Quality management system requires the adoption of a state strategy and mechanism for implementation of quality system according to the Recommendations of WHO and Council of Europe. Legal framework should include the following sections: principles of quality management, quality assurance, personnel, premises and equipment, documentation, collection, testing and processing, storage and distribution, self-verification, quality control of final products. Taking into consideration the importance of blood components usage in health care establishments, it is necessary to develop new promising methods for quality assessment of blood components. For obtaining reliable results of quality control indicators it is necessary to adopt standardized methods and procedures, and quality assessment criteria must be installed and approved.

Considerable proportion of legal and regulatory acts (30) regulate general issues of activity arrangements of blood service establishments, formation of stuff and logistic resources, definition of internal regulations and system of labour protection, financial, economic and legal relations of blood service establishments. Among them there are 3 documents up to 5 years; 4 - from 5 to 10 years; 14 - from 10 to 15 years; 8 - from 15 to 20 years.

In the section "Clinical Transfusiology" regulatory framework requires some additional revision and adoption of new documents relating to the usage of blood, blood components and products based on principles of evidence-based medicine. Calculation and procedure for investigation of reactions and complications related to transfusion of blood products are not defined at the state level. Creation of haemovigilance system at regional and national levels requires using of information technologies.

\section{Conclusions}

1. The largest number of legal and regulatory acts (35) was adopted during 1998-2002, in subsequent periods declining tendency was recorded; 2003-2007 - 25 documents; 2008-2012 19 documents. Almost $50 \%$ of legal and regulatory acts are documents of direct effect on functions of blood service establishments.

2. Legal framework of blood service of Ukraine concerning donor selection, procurement, transportation and issue of blood components requires harmonization with Recommendations and Resolutions of Council of Europe and WHO.

3. Immunological trials of donors and recipients need revising and determining minimum standards for blood service establishments and health care establishments.

4. Creation of a quality system and support and development of its effectiveness in every blood service establishment requires regulatory framework based on Recommendations of $\mathrm{WHO}$ and Council of Europe and achievements of USA, Japan, European countries and others.

5. Formation of a new section of clinical transfusion "Blood components for perinatal 
application and use for infants and younger children" will help to standardize transfusion tactics in perinatal centers and children's hospitals and departments.

6. Transfusion of blood and blood components requires standardization of accounting storage conditions and creating haemovigilance system with issuing national recommendations or guidelines for clinical transfusion and relevant orders of Ministry of Health of Ukraine.

\section{References}

1. Москаленко В. Ф. Принципи побудови оптимальної системи охорони здоров'я. Український контекст / В. Ф. Москаленко. - К. : Книга плюс, 2008. - С. 10.

2. Про загальнодержавну програму адаптації законодавства України до законодавства Європейського Союзу : Закон України № 1620-IV від 18 березня 2004 р. // Відомості Верховної Ради України. - 2004. - № 29. - С. 367.

\section{НОРМАТИВНО-ПРАВОВА БАЗА СЛУЖБИ КРОВІ УКРАЇНИ}

А.М. Чугрієв

Житомирський обласний центр крові, Україна

Мета: визначити стан нормативно-правової бази, що регламентує роботу закладів служби крові України станом на 01.01.2013 р.

Матеріали і методи. Вивчалися чинні документи, якими регламентовано діяльність служби крові в Україні.

Результати. Встановлено, що діяльність закладів служби крові України регулюють 107 нормативноправових актів, у тому числі 15 законів України, 2 укази Президента України, 16 постанов Кабінету Міністрів України, 37 наказів МОЗ України, 14 міжвідомчих наказів, 9 наказів МОЗ СРСР та УРСР, 1 постанова Держкомітету із стандартів СРСР та 10 методичних рекомендацій МОЗ і НАМН України. Мають термін давності до 5 років 19 актів, від 5-10 років - 25 актів, від 10 до 15 років - 35 актів, від 15 до 20 років - 13 актів, від 20 до 25 років - 8 актів і вік 25-40 років мають 7 нормативно-правових акти.

Висновки. Нормативна база служби крові України потребує гармонізації з Рекомендаціями і резолюціями ВООЗ і Ради Європи, з Керівництвом по виготовленню, використанню і забезпеченню якості компонентів крові.

КЛЮЧОВІ СЛОВА: нормативно-правова база, служба крові, статистичні форми звітності, система haemovigilance, законодавство Європейського Союзу.

\section{НОРМАТИВНО-ПРАВОВАЯ БАЗА СЛУЖБЫ КРОВИ УКРАИНЫ}

А.Н. Чугриев

Житомирский областной центр крови, Украина

Цель: определить состояние нормативно-правовой базы, регламентирующей работу учреждений службы крови Украины по состоянию на 01.01.2013 г.

Материалы и методы. Изучены действующие документы, которыми регламентирована деятельность службы крови в Украине.

Результаты. Установлено, что деятельность учреждений службы крови Украины регулируют 107 нормативно-правовых актов, в том числе 15 законов Украины, 2 указа Президента Украины, 16 постановлений Кабинета Министров Украины, 37 приказов МЗ Украины 14 межведомственных приказов, 9 приказов МЗ СССР та УССР, 1 постановление Госкомитета по стандартам СССР и 10 методических рекомендаций МЗ и НАМН Украины. Имеют срок давности до 5 лет 19 актов, от 5-10 лет - 25 актов, от 10 до 15 лет - 35 актов, от 15 до 20 лет - 13 актов, от 20 до 25 лет - 8 актов и возраст 25-40 лет имеют 7 нормативно-правовых актов.

Выводы. Нормативная база службы крови Украины требует гармонизации с Рекомендациями и резолюциями ВОЗ и Совета Европы, с Руководством по изготовлению, использованию и обеспечению качества компонентов крови.

КЛЮЧЕВЫЕ СЛОВА: нормативно-правовая база, служба крови, статистические формы отчетности, система haemovigilance, законодательство Европейского Союза.

Рукопис надійшов до редакції 10.11.2014 р.

Відомості про автора:

Чугрієв Анатолій Миколайович - к.мед.н., головний лікар Житомирського обласного центру крові; тел.: +38(412) 39-58-57. 